\title{
AGROCHEMICALS AND STEM CUTTING TYPES FOR PLANTLET PRODUCTION OF Spondias sp. ${ }^{1}$
}

\author{
NOUGLAS VELOSO BARBOSA MENDES ${ }^{2 *}$, FRANCISCO XAVIER DE SOUZA ${ }^{3}$, ADROALDO GUIMARÃES \\ ROSSETTI $^{3}$, WILLIAM NATALE ${ }^{2}$, MÁRCIO CLEBER DE MEDEIROS CORRÊA ${ }^{2}$
}

\begin{abstract}
Umbu-caja (Spondias sp.) is a fruit tree native to the Northeast region of Brazil, which is grown because of its highly valuable fruits for fruit processing industries. The objective of this work was to evaluate the effect of agrochemical applications and cutting types on the rooting and development of Spondias sp. plantlets. The experiment was conducted at the experimental field of the Embrapa Tropical Agroindustry, in Pacajus, CE, Brazil. A randomize block experimental design was used, with five treatments - control (T1); cuttings with two lesions at the base $(\mathrm{CL})+$ rooting gel $(\mathrm{RG})\left(\right.$ Sela Gel $\left.{ }^{\circledR}\right)(\mathrm{T} 2)$; CL + rooting fertilizer $(\mathrm{RF})$ $\left(\right.$ Radimax $^{\circledR}$ ) (T3); cuttings with two transversal cross sections at the base (CS) + RG (T4); and CS + RF (T5). The environments (blocks) used were: full sun; 100\% shade ceiling; 50\% shade walls and ceiling; and 50\% shade ceiling. The plots consisted of eight cuttings, totaling 160 cuttings. Propagules were taken from Spondias sp. plants to make woody cuttings with length of $25 \mathrm{~cm}$, diameter of $29.7 \mathrm{~mm}$, and mean bud per cutting of 8.7. All cuttings were immediately treated with a $0.05 \%$ sodium hypochlorite solution for four minutes before making the lesions and transversal cross sections and applying the treatments. The RG was applied by brushstroke, and the RF was applied by immersion in an aqueous solution of $10 \mathrm{~mL} \mathrm{~L} \mathrm{~L}^{-1}$ for 10 minutes. The cuttings were planted into 6-liter black plastic pots filled with a pasteurized mixture of vermiculite, coconut husk powder, ground leaf fibers of Copernicia prunifera, and carbonized rice husk $\left(2: 1: 1: 1 ; \mathrm{v} \mathrm{v}^{-1}\right)$. The treatments and blocks significantly affected the rooting and development of cuttings. The treatment with CS and application of the RG (T4) promoted root callus formation, rooting, and vigorous development of plantlets, whereas the RF (T3 and T5) failed to promote root formation.
\end{abstract}

Keywords: Vegetative propagation. Cutting. Spondias.

\section{AGROQUÍMICOS E LESÕES EM ESTACAS DE CAULE NA FORMAÇÃO DE MUDAS DE UMBU- CAJAZEIRA}

RESUMO - A umbu-cajazeira (Spondias sp.), frutífera nativa do Nordeste brasileiro, produz frutos muito valorizados pelas agroindústrias. O objetivo deste trabalho foi avaliar a aplicação de agroquímicos e lesões no enraizamento e na formação de mudas/estacas, foi conduzido na Embrapa em Pacajus, CE, em blocos ao acaso,

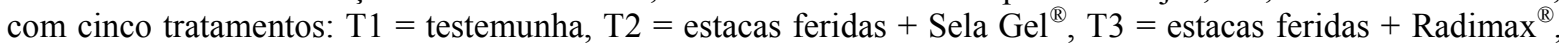
$\mathrm{T} 4=$ estacas incisadas + Sela Gel ${ }^{\circledR}$ e T5 = estacas incisadas + Radimax $^{\circledR}$. Os ambientes (blocos): pleno sol; teto com plena sombra; sombrite $50 \%$ nas laterais e no teto; e sombrite $50 \%$ no teto. As parcelas tinham oito estacas, totalizando 160 estacas. Dos propágulos retirados de plantas, preparam-se estacas lenhosas, com $25 \mathrm{~cm}$ de comprimento e médias de 29,7 mm de diâmetro e 8,7 gemas/estaca. Em seguida foram tratadas com solução de hipoclorito de sódio a 0,05\%/4 minutos; depois fez-se os ferimentos e as incisões e aplicou-se o Sela Gel ${ }^{\circledR}$ por pincelamento e o Radimax ${ }^{\circledR}$ por imersão em solução de $10 \mathrm{~mL} / \mathrm{L}$ d'água/10 minutos. O plantio foi em vasos plásticos pretos, com capacidade $6 \mathrm{~L}$, cheios com vermiculita + pó de cascas de coco + bagana de carnaúba triturada + cascas de arroz carbonizada $(2: 1: 1: 1, \mathrm{v} / \mathrm{v})$, previamente pasteurizados. Entre os tratamentos e os blocos houve diferenças significativas. A incisão e a aplicação do Sela Gel ${ }^{\circledR}$ induziram a formação de calo, o enraizamento e a formação de mudas vigorosas, enquanto o Radimax ${ }^{\circledR}$ não induziu o enraizamento.

Palavras-chave: Propagação vegetativa. Estaquia. Spondias.

\footnotetext{
${ }^{*}$ Corresponding author

${ }^{1}$ Received for publication in $01 / 25 / 2019$; accepted in 09/16/2019.

Paper extracted from the master's thesis of the first author.

${ }^{2}$ Department of Plant Sciense, Universidade Federal do Ceará, Fortaleza, CE, Brazil; nouglasmendes@hotmail.com - ORCID: 0000-00034873-3206, natale@ufc.br - ORCID: 0000-0001-9572-4463, mcleber@ufc.br - ORCID: 0000-0002-0702-4959.

${ }^{3}$ Research and Development, Embrapa Agroindústria Tropical, Fortaleza, CE, Brazil; xavier.souza@embrapa.br - ORCID: 0000-00027677-346X, adroaldo.rossetti@embrapa.br-ORCID: 0000-0002-0150-4089.
} 


\section{INTRODUCTION}

Umbu-caja (Spondias sp.) is a fruit tree of the Anacardiaceae family (MITCHELL; DALY, 2015). It is a xerophyte species probably native to the Brazilian Semiarid region. According to Giacometti (1993), it is a hybrid between the umbu tree $(S$. tuberosa Arruda) and the caja tree (S. mombin L.); Silva Júnior et al. (2004) called it umbu-caja and indicated that it is a hybrid between these species. Almeida, Carvalho and Guerra (2007) examined the cariology and in situ genomic hybridization and concluded that umbu-caja is not a hybrid; thus, Machado and Carvalho (2015) performed molecular, morphometric, morphological, and temporal divergence investigations and concluded that the plant has a distinct lineage and named it Spondias bahiensis sp. nov.

Spondias sp. trees are distributed in backyards in urban and rural areas of the Northeast region of Brazil; There are centenary, productive plants (about $1,500 \mathrm{~kg}$ of fruits per harvest season) producing fruits for human and animal consumption. The fruits are drupes, named umbu-caja, caja-umbu, or cajarana. The harvesting is performed by picking the fruits from trees in natural environments or grown without any input or agricultural practice.

Most Spondias sp. drupes are sterile, i.e., without seeds. This is the main reason for the propagation of this plant by cutting, which is traditionally done with stem cuttings whose rooting is low and slow, although some growers claim that this plant has easy rooting. Contrastingly, the literature shows low rooting percentages, around $25 \%$ to $35 \%$ (FAÇANHA, 1997; LOPES, 1997; LIMA et al., 2002; RIBEIRO et al., 2007; BASTOS, 2010), proving that the rooting of cuttings of Spondias $\mathrm{sp}$. is difficult.

According to Hartmann et al. (2011), several exogenous and endogenous factors are involved in the cutting rooting capacity, such as season, environmental conditions, propagation system, type of propagule, and the plant nutritional and phytosanitary status, phenological stage, and species. Propagules taken from plants at the end of the vegetative resting stage, defoliated, and with swollen buds are recommended for Spondias spp. (SOUZA; COSTA, 2010).

Adventitious root formation is a complex process dependent on several factors, such as production of endogenous phytoregulators and carbohydrates, presence of dormant buds, and emergence of sprouts (SMART et al., 2003). This is due to morphological changes associated with root formation in cuttings, such as callus formation and root development (THOMAS; SCHIEFELBEIN, 2002).

Many plant species respond to auxin application and to cuts at the base of their cuttings, especially woody cuttings. These cuts stimulate cell division, formation of callus and radical primordia, hormone and water absorption, and root emission by disruption of the sclerenchyma rings (HARTMANN et al., 2011).

This context shows the need for studies on rooting and plantlet formation by cuttings of Spondias sp. Thus, this work was carried out to evaluate the application of agrochemicals and the use of cuttings with lesions made at the base of cuttings on the rooting and formation of Spondias sp. plantlets.

\section{MATERIAL AND METHODS}

The experiment was conducted from October 2016 to January 2017 at the Experimental Field of the Embrapa Tropical Agroindustry in Pacajus, CE, Brazil. The experimental period presented average air temperature of $28.15^{\circ} \mathrm{C}$ and relative air humidity of $72.79 \%$ (Figure 1). A randomize block experimental design was used, with five treatments control (cuttings without any treatment) (T1); cuttings with two lesions at the base $(\mathrm{CL})+$ rooting gel (RG) (Sela Gel $\left.{ }^{\circledR}\right)(\mathrm{T} 2)$; CL + rooting fertilizer (RF) $\left(\right.$ Radimax $^{\circledR}$ ) (T3); cuttings with two transversal cross sections at the base (CS) + RG (T4); and CS + RF (T5). The environments (blocks) used were: full sun; $100 \%$ shade ceiling; $50 \%$ shade walls and ceiling; and 50\% shade ceiling. The plots consisted of eight cuttings, totaling 160 cuttings.

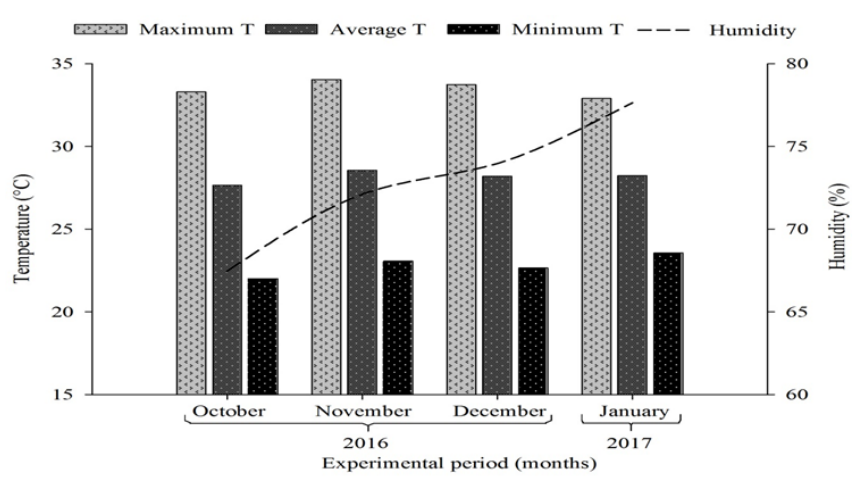

Figure 1. Means for maximum, average, and minimum air temperatures and relative air humidity during the experimental period. 
Propagules were taken from wood branches of two 18-year-old Spondias sp. plants at the Embrapa Experimental Field in Pacajus, in October 2017. The propagules were left upright under the plant's canopy for seven days. Subsequently, cuttings with length of $25 \mathrm{~cm}$, diameter of $29.7 \mathrm{~mm}$, and mean bud per cutting of 8.7 were prepared. They were then covered with moistened jute bags until the following day, when they were immersed in a $0.05 \%$ sodium hypochlorite solution for 4 minutes. Lesions (two incisions with the tip of a knife) were made for the T2 and T3 treatments, and transversal cross sections (two cuts with a knife, taking approximately $3 \mathrm{~cm}$ of the bark on opposite sides of the base of the cuttings) were made for the T4 and T5 treatments (Figure 2). The RG was applied by brushstroke, and the RF was applied by immersing them in an aqueous solution of $10 \mathrm{~mL} \mathrm{~L}^{-1}$ for 10 minutes.

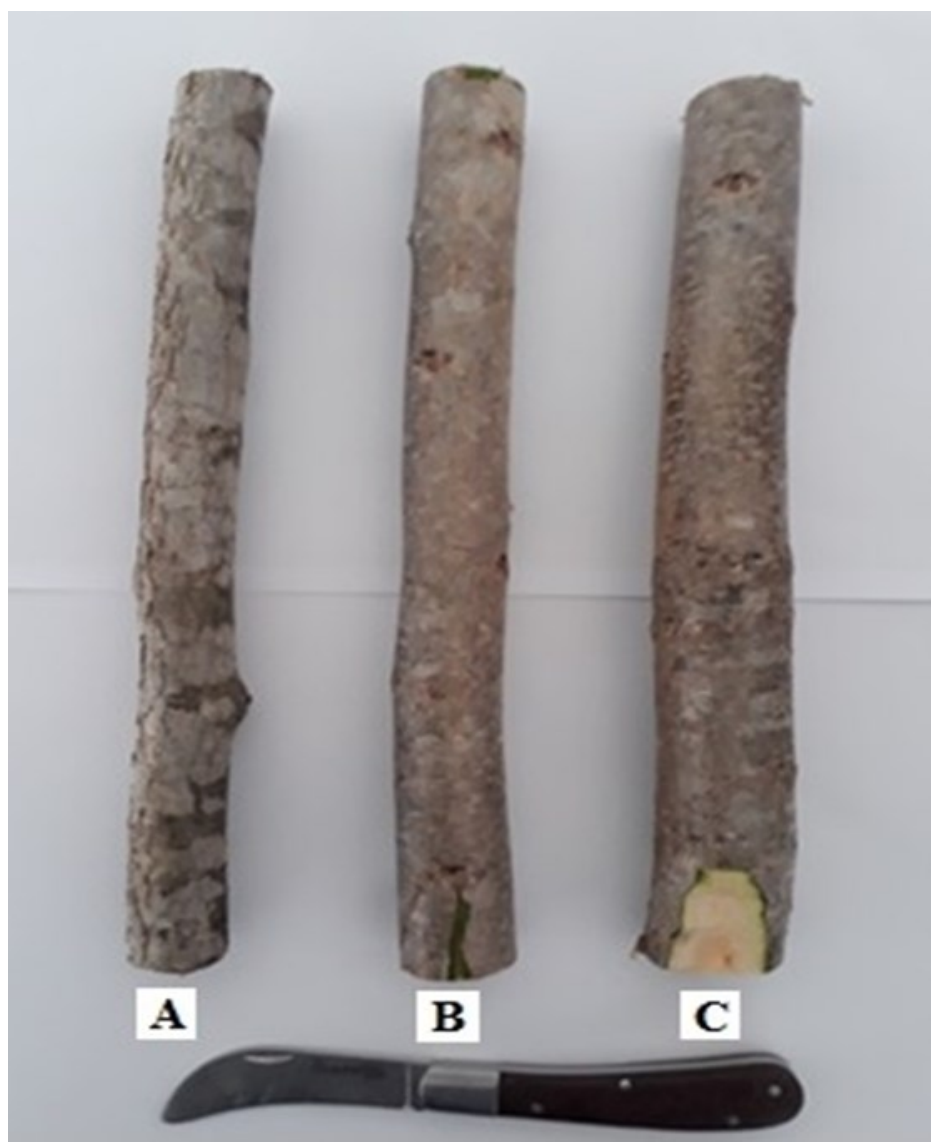

Figure 2. Preparation of Spondias sp. cuttings for the experiment - control (A), and lesions (B) and transversal cross sections $(\mathrm{C})$ at the base of the cuttings.

According to the manufacturer, the rooting gel (RG) (Sela $\mathrm{Gel}^{\circledR}$ ) was formulated to prevent embolism of cuttings after cutting, forming a protective film to prevent air entry, and to promote rooting due to its concentration of indole-3-butyric acid (3.000 mg. $\mathrm{L}^{-1}$ ) (ECOPLANET, 2012). The rooting fertilizer used $\left(\right.$ Radimax $^{\circledR}$ ) was developed as a foliar fertilizer and a rooting improver based on an NPK formulation with specific amino acids and trace elements that promote root development (CODA, 2016).

The cuttings were planted, 10 minutes after the application of the treatments, into 6-liter black plastic pots filled with a pasteurized mixture of vermiculite, coconut husk powder, ground leaf fibers of Copernicia prunifera, and carbonized rice husk $\left(2: 1: 1: 1 ; \mathrm{v} \mathrm{v}^{-1}\right)$, which were previously pasteurized, i.e., submerged in water at $90{ }^{\circ} \mathrm{C}$ for 4 minutes.
The 160 cuttings were grown in hoop houses $(40 \times 60 \mathrm{~cm}$ transparent plastic bags on wire rods attached to the pots, and tied with rubber). The pots were placed inside polypropylene containers on wooden, concrete, and iron supports, in the four environments for rooting (stratified as blocks).

The plants were watered twice a week, by placing water $(1.0 \mathrm{~L})$ in the containers under the pots, through capillary absorption, without wetting the cuttings. The plastic bags of the hoop houses were removed at 34 days after the planting of the cuttings because of the contact of the shoots with the inner surface of the hoop houses.

The percentages of cuttings with callus and rooting formations, percentage of plantlets suitable for replanting (vigorous plantlets with more than four developed leaves), and number of leaflets were evaluated 90 days after the cuttings were planted. 
Statistical analysis was performed using SAS software (2008); the data were subjected to analysis of variance and transformed into $\sqrt{\mathrm{x}}+1$ (STEEL; TORRIE, 1980). The means of all variables in the treatments were compared by the REGWQ and Dunnett tests $(p<0.05)$.

\section{RESULTS AND DISCUSSION}

The analysis of variance showed significant differences $(p<0.01)$ by the $\mathrm{F}$ test for all variables in all evaluated treatments. The environments presented no significant difference $(p<0.05)$ only for the percentage of cuttings with callus (Table 1). The overall means were $85 \%$ cuttings with callus, $42.5 \%$ cuttings with rooting, $35.62 \%$ plantlets suitable for replanting, and 67.91 leaflets per cut, denoting the high vigor of the plantlets. The coefficients of variation for percentage of cuttings with callus, rooting, and plantlets suitable for replanting were below $14 \%$, indicating a low dispersion of the data from the means (Table 1). However, the number of leaflets had a coefficient of variation of $82.7 \%$, which is explained by the effects of treatments and propagules. Despite these propagules were homogeneous and originated from the same clone, they had variations in organic compound contents, bud stage, and unknown endogenous factors, which may have affected the shoot, callus, and root formation and the development of leaflets. The cuttings that sprouted and rooted had probably more nutrient reserves and buds, which induced and increased the emission of shoots and development of leaves and leaflets.

Table 1. Analysis of variance for percentage of cuttings with callus, percentage of cuttings with rooting, percentage of plantlets suitable for replanting, and number of leaflets in stem cuttings of Spondias sp.

\begin{tabular}{|c|c|c|c|c|c|c|c|c|c|}
\hline \multirow[t]{2}{*}{ Source of variation } & \multirow{2}{*}{$\begin{array}{l}\text { Degrees } \\
\text { of } \\
\text { freedom }\end{array}$} & \multicolumn{2}{|c|}{$\begin{array}{l}\text { Cuttings with } \\
\text { callus }(\%)^{1}\end{array}$} & \multicolumn{2}{|c|}{$\begin{array}{l}\text { Cuttings with } \\
\text { rooting }(\%)\end{array}$} & \multicolumn{2}{|c|}{$\begin{array}{l}\text { Plantlets suitable } \\
\text { for replanting }(\%)\end{array}$} & \multicolumn{2}{|c|}{ Number of leaflets } \\
\hline & & MS & $\operatorname{Pr}>F^{2}$ & MS & $\operatorname{Pr}>\mathrm{F}$ & MS & $\operatorname{Pr}>\mathrm{F}$ & MS & $\operatorname{Pr}>\mathrm{F}$ \\
\hline Treatment $(\mathrm{T})$ & 4 & 0.1137 & 0.0001 & 0.7576 & 0.0001 & 0.6128 & 0.0001 & 535.1519 & 0.0001 \\
\hline Environment (E) & 3 & 0.0257 & 0.2314 & 0.0715 & 0.0315 & 0.0726 & 0.0305 & 84.4135 & 0.0012 \\
\hline $\mathrm{T} \times \mathrm{E}$ & 12 & 0.0400 & 0.0123 & 0.0134 & 0.8647 & 0.0252 & 0.3974 & 33.9983 & 0.1158 \\
\hline Residue & 140 & 0.0178 & & 0.0236 & & 0.0237 & & 21.9924 & \\
\hline $\mathrm{CV}(\%)$ & & \multicolumn{2}{|c|}{9.86} & \multicolumn{2}{|c|}{13.06} & \multicolumn{2}{|c|}{13.43} & \multicolumn{2}{|c|}{82.70} \\
\hline Mean & & \multicolumn{2}{|c|}{85.00} & \multicolumn{2}{|c|}{42.50} & \multicolumn{2}{|c|}{35.62} & \multicolumn{2}{|c|}{67.91} \\
\hline
\end{tabular}

MS $=$ Mean square. ${ }^{1}$ Data transformed into $\sqrt{\mathrm{X}}+1 .{ }^{2}$ Significance level of the $\mathrm{F}$ test.

The percentages of cuttings that had sprouting were $6.9 \%$ at 13 days after planting (DAP), and $55.7 \%$ at 20 DAP, varying from $50 \%$ in cuttings with cuttings with two lesions at the base (CL) + rooting gel (RG) (T2) to $59.4 \%$ in cuttings with two transversal cross sections at the base (CS) + rooting fertilizer (RF). The last evaluation (90 DAP) showed a higher number of sprouted cuttings and many with differentiated leaflets; $91.87 \%$ of the cuttings had at least one sprout, varying between treatments. The cuttings without any treatment (control) had lower sprouting percentage $(87.5 \%)$, and those with CS + RG showed higher sprouting percentage (96.87\%). These results indicate the rooting of cuttings, since the emission of shoots by cuttings occurs due to their nutritional reserves, which are essential for synthesis of photoassimilates, hormones, and cofactors that induce formation of callus and adventitious roots (HARTMANN et al., 2011). Rooting is essential for differentiation, maintenance, and continuity of the development of leaflets, leaves, and branches, i.e., the formation of a new plant.

The environments used for formation of Spondias sp. plantlets showed significant differences for percentage of cuttings with rooting, percentage of plantlets suitable for replanting, and number of leaflets. The cuttings under $100 \%$ shade ceiling had the highest percentage of cuttings with rooting $(55 \%)$, percentage of plantlets suitable for replanting $(47.5 \%)$, and number of leaflets per plantlets (79.95). The lowest means were found for cuttings under full sun (Figure 3). 


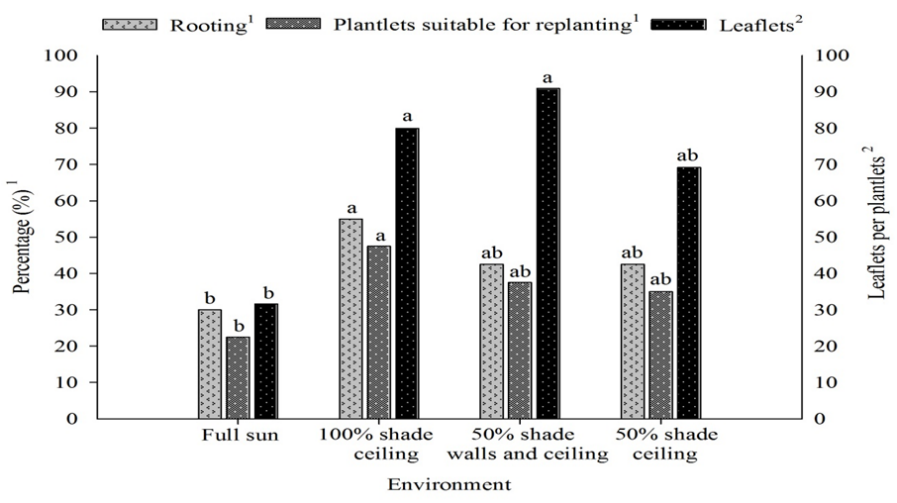

Figure 3. Percentage of cuttings with rooting, percentage of plantlets suitable for replanting, and number of leaflets per plantlets of stem cuttings of Spondias sp.

The treatments presented significant differences for all variables by the REGWQ test $(p<0.05)$ (Table 2). The highest percentages of cutting with callus were found for those in the treatment $\mathrm{CS}+\mathrm{RG}(100 \%)$, followed by $\mathrm{CS}+\mathrm{RF}$
$(93.75 \%)$ and $\mathrm{CL}+\mathrm{RG}(87.5 \%) ; 81.25 \%$ of the cuttings in the treatment $\mathrm{CL}+\mathrm{RF}$ had callus, no differing from the control, which had $62.5 \%$ cuttings with callus.

Table 2. Percentage of cuttings with callus, percentage of cuttings with rooting, percentage of plantlets suitable for replanting, and number of leaflets per plantlets in stem cuttings of Spondias sp.

\begin{tabular}{ccccc}
\hline Treatments & $\begin{array}{c}\text { Cuttings with } \\
\text { callus (\%) }\end{array}$ & $\begin{array}{c}\text { Cuttings with } \\
\text { rooting (\%) }\end{array}$ & $\begin{array}{c}\text { Plantlets suitable } \\
\text { for replanting (\%) }\end{array}$ & Number of leaflets \\
\hline Control & $62.50 \mathrm{~b}$ & $12.50 \mathrm{~b}$ & $9.38 \mathrm{c}$ & $18.06 \mathrm{~b}$ \\
$\mathrm{CL}+\mathrm{RG}$ & $87.50 \mathrm{a}$ & $68.75 \mathrm{a}$ & $56.25 \mathrm{~b}$ & $112.34 \mathrm{a}$ \\
$\mathrm{CL}+\mathrm{RF}$ & $81.25 \mathrm{ab}$ & $9.38 \mathrm{~b}$ & $9.38 \mathrm{c}$ & $17.56 \mathrm{~b}$ \\
$\mathrm{CS}+\mathrm{RG}$ & $100.00 \mathrm{a}$ & $93.75 \mathrm{a}$ & $84.38 \mathrm{a}$ & $156.00 \mathrm{a}$ \\
$\mathrm{CS}+\mathrm{RF}$ & $93.75 \mathrm{a}$ & $28.13 \mathrm{~b}$ & $18.75 \mathrm{c}$ & $35.56 \mathrm{~b}$ \\
\hline
\end{tabular}

Means followed by the same letter in the column are significantly different by the REGWQ test at $p \leq 0.05$. CL $=$ cuttings with two lesions at the base; $\mathrm{CS}=$ cuttings with two transversal cross sections at the base.

The highest percentages of cuttings with rooting were found in the treatments $\mathrm{CS}+\mathrm{RG}$ $(93.75 \%)$ and CL + RG (68.75\%), differing from the other treatments, which presented less than $28.14 \%$ cuttings with rooting (Table 2). Façanha (1997), Vieira (2013), and Bastos et al. (2014) found percentages of cuttings with rooting of $22.5 \%$, $20.74 \%$, and $35 \%$, respectively, confirming that Spondias sp. cutting rooting is difficult (SOUZA; COSTA, 2010). However, in the present study, the percentages of cuttings with rooting in the treatments with RG were higher than those found by those studies. This difference was probably due to the concentrations of rooting inhibitor substances present in the cuttings and the concentrations of the rooting improver used in the present study. The RG used (Sela Gel ${ }^{\circledR}$ ) has an indole-3-butyric acid (IBA) concentration of $3 \mathrm{~g} \mathrm{~L}^{-1}$, which may have provided an adequate balance between these substances, leading to a better rooting of the cuttings. According to Pasqual et al. (2001), an adequate endogenous balance between rooting promoters and inhibitors is needed for the rooting initial process.

The lesions and transversal cross sections made in the base of the cuttings influenced positively the callus formation (Figure 4A), confirming that, in some species, lesions or transversal cross sections at the base of cuttings may promote callus formation (HARTMANN et al., 2011). The rooting of the cuttings was influenced by the agrochemical used; the RG used was more efficient for rooting of Spondias sp. cuttings (Figure 4B) than the RF probably due to its IBA concentration and promotion of protection against cutting embolism. 

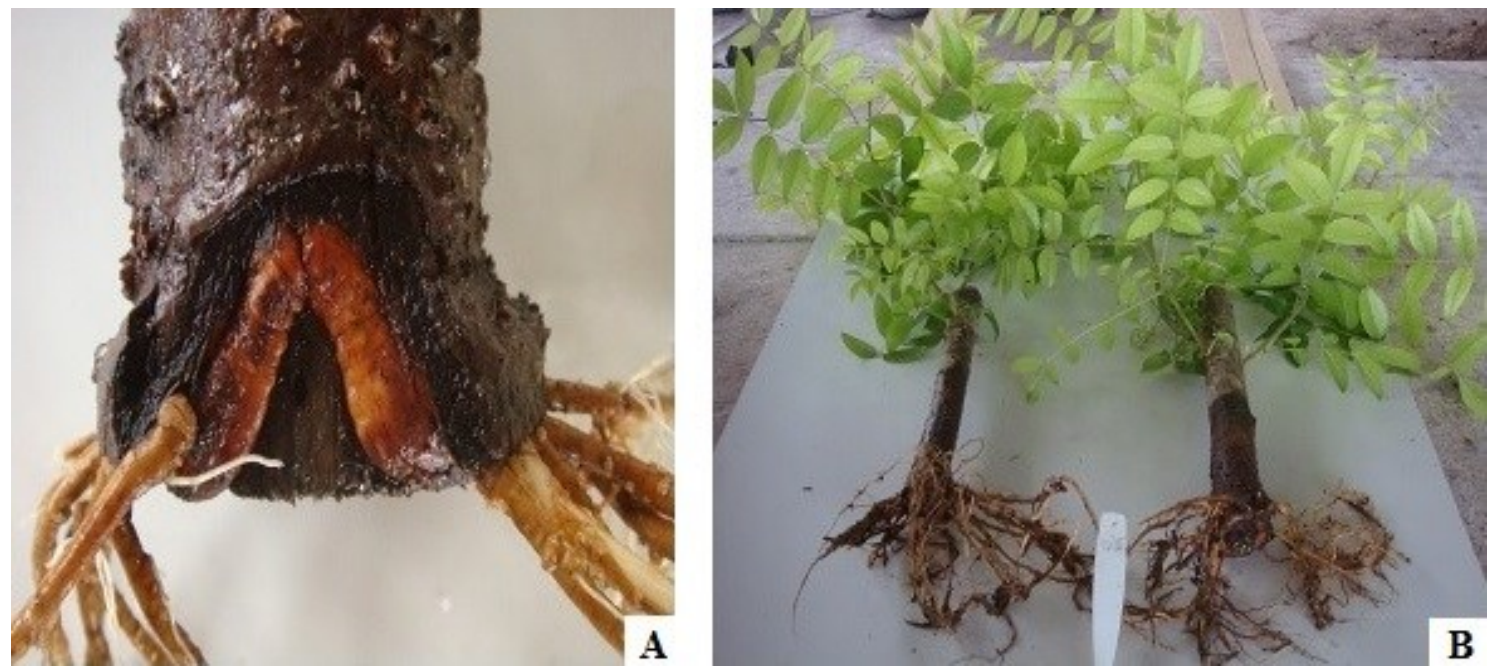

Figure 4. Formations of callus and adventitious roots (A) and plantlets (B) from Spondias sp. stem cuttings with cross section at the base and treated with rooting gel $\left(\right.$ Sela Gel $\left.{ }^{\circledR}\right)$.

The highest percentages of plantlets suitable for replanting were found in the treatments with CS $+\mathrm{RG}(84.38 \%)$ and $\mathrm{CL}+\mathrm{RG}$ (56.25\%), differing from the other treatments, which had percentages lower than $18.8 \%$ (Table 2). The highest number of leaflets per plantlets (more vigorous plantlets) were found in the treatments CS + RG (156) and CL + RG (122.34), differing from the other treatments, which had means lower than 35.60. Tosta et al. (2012) found mean of 38.4 leaflets per Spondias sp. cuttings treated with $4,218 \mathrm{mg} \mathrm{L}^{-1}$ of IBA.

According to the Dunnett's test, the percentages of cuttings with callus, rooting, and plantlets suitable for replanting and the number of leaflets per cutting of plants treated with agrochemicals had significant differences when compared to the control (Table 3 ). The treatments $\mathrm{CS}+\mathrm{RG}$ and $\mathrm{CL}+\mathrm{RG}$ had $25 \%$ and $37.5 \%$ more cuttings with callus, respectively. The treatment CS + RF had $31.25 \%$ more cuttings with callus than the control. The highest percentage of cuttings with rooting were found in the treatments $\mathrm{CS}+\mathrm{RG}$ $(56.25 \%)$ and $\mathrm{CL}+\mathrm{RG}(81.25 \%)$. The treatments $\mathrm{CS}$ $+\mathrm{RG}$ and $\mathrm{CL}+\mathrm{RG}$ showed better results for plantlets suitable to replanting and number of leaflets per cutting when compared to the control. This denotes the effect of the RG combined with lesions or transversal cross sections on the rooting and vigor of Spondias sp. cuttings.

Table 3. Comparison between treatments for percentages of cuttings with callus, rooting, and plantlets suitable for replanting and number of leaflets in Spondias sp. stem cuttings.

\begin{tabular}{ccccc}
\hline Treatments & $\begin{array}{c}\text { Cuttings with } \\
\text { callus (\%) } \\
\text { Difference }\end{array}$ & $\begin{array}{c}\text { Cuttings with } \\
\text { rooting (\%) } \\
\text { Difference }\end{array}$ & $\begin{array}{c}\text { Cuttings suitable } \\
\text { for replanting (\%) } \\
\text { Difference }\end{array}$ & $\begin{array}{c}\text { Number of } \\
\text { leaflets } \\
\text { Difference }\end{array}$ \\
\hline $\mathrm{CL}+\mathrm{RG} \times$ Control & $25.00 *$ & $56.25 *$ & $46.87 *$ & $94.28 *$ \\
$\mathrm{CL}+\mathrm{RF} \times$ Control & 18.75 & -03.12 & 00.00 & -0.50 \\
$\mathrm{CS}+\mathrm{RG} \times$ Control & $37.50 *$ & $81.25 *$ & $75.00 *$ & $137.94 *$ \\
$\mathrm{CS}+\mathrm{RF} \times$ Control & $31.25 *$ & 15.62 & 9.37 & 17.50 \\
\hline
\end{tabular}

*Significantly different by the Dunnett's test at $p<0.05$.

\section{CONCLUSIONS}

Spondias sp. (umbu-caja) cuttings with transversal cross sections and treated with a rooting gel (Sela $\mathrm{Gel}^{\circledR}$ ) had callus formation, rooting, and formed vigorous plantlets.

The use of a rooting fertilizer $\left(\right.$ Radimax $\left.^{\circledR}\right)$ in Spondias sp. cuttings promotes no rooting or plantlet formation.

Environments that provide at least $50 \%$ shade can be used to produce Spondias sp. cuttings.

\section{AKNOWLEDGEMENTS}

The authors thank the Federal University of Ceará (UFC) and the Embrapa Tropical Agroindustry for their institutional and logistical support, and the Brazilian Coordination for the Improvement of Higher Education Personnel (CAPES) for granting the scholarship to the first author. 


\section{REFERENCES}

ALMEIDA, C. C. S.; CARVALHO, P. C. L.; GUERRA, M. Karyotipe differentiation among Spondias species and the putative hybrid umbu-cajá (Anacardiaceae). Botanical Journal of the Linnaean Society, v. 155, n. 4, p. 541-547, 2007.

BASTOS, L. P. Caracterização de frutos e propagação vegetativa de Spondias. 2010. 53 f. Dissertação (Mestrado em Ciências Agrárias: Área de concentração em Fitotecnia) - Universidade Federal do Recôncavo da Bahia, Cruz das Almas, 2010 .

BASTOS, L. P. et al. Propagação vegetativa de umbu-cajazeira. Enciclopédia biosfera, v. 10, n. 18, p. $2508,2014$.

CODA - Radimax. Disponível em: <http:// www.coda-agri.com/pt/produtos/aminoacidosebiostimulants>. Acesso em 08 de abril de 2018.

ECOPLANET - Sela Gel. Disponível em: <http:// www.ecoplanet.agr.br>. Acesso em: 08 de abr. de 2018 .

FAÇANHA, R. E. Enraizamento de estacas de caule de umbu-cajá (Spondias sp.). 1997. 26 f. Monografia (Graduação em Agronomia) - Centro de Ciências Agrárias, Universidade Federal do Ceará, Fortaleza, 1997.

GIACOMETTI, D. C. Recursos genéticos de fruteiras nativas do Brasil. In: SIMPÓSIO NACIONAL DE RECURSOS GENÉTICOS DE FRUTEIRAS NATIVAS, 1992, Cruz das Almas. Anais... Cruz das Almas: Embrapa-CNPMF, 1993. p. 13-27.

HARTMANN, H. T. et al. Hartmann and Kester's Plant propagation: principles and practices. 8. ed. New Jersey: Prentice Hall, 2011. 915 p.

LIMA, A. K. C. et al. Propagação de cajarana (Spondias sp.) e cirigüela (Spondias purpurea) por meio de estacas verdes enfolhadas, nas condições climáticas de Mossoró-RN. Revista Caatinga, v. 15, n. 1/2, p. 33-38, 2002.

LOPES, W. F. Propagação assexuada de cajá (Spondias mombim L.) e cajá-umbu (Spondias spp.) através de estacas. 1997. $41 \mathrm{f}$. Monografia (Graduação em Agronomia) - Centro de Ciências Agrárias, Universidade Federal da Paraíba, Areia, 1997.

MACHADO, M. C.; CARVALHO, P. C. L.; van den Berg, C. Domestication, hybridization, speciation, and the origins of an economically important tree crop of Spondias (Anacardiaceae) from the brazilian caatinga dry forest. Neodiversity, v. 8, n. 1, p. 8-49, 2015.

MITCHELL, J. D.; DALY, D. C. A revision of Spondias L. (Anacardiaceae) in the Neotropics. PhytoKeys, v. 55, n. 1, p. 1-92, 2015.

PASQUAL, M. et al. Fruticultura comercial: propagação de plantas frutíferas. 1. ed. Lavras, MG: UFLA/FAEPE, 2001. 137 p.

RIBEIRO, M. C. C. et al. Efeito das folhas e do tipo de estaca no enraizamento da cajarana (Spondias sp.). Revista Verde, v. 2, n. 2, p. 37-41, 2007.

SAS INSTITUTE INC. SAS/STAT: user's Guide. Version 9.2 Cary, NC: SAS Institute Inc., 2008.

SILVA JÚNIOR, J. F. et al. Collecting, ex situ conservation and characterization of "cajáumbu" (Spondias mombim x Spondias tuberosa) germ-plasm in Pernambuco State, Brazil. Genetic Resources and Crop Evolution, v. 51, n. 4, p. 343 349, 2004.

SMART, D. R. et al. Dormant buds and adventitious root formation by Vitis and other woody plants. Journal of Plant Growth Regulation, v. 21, n. 4, p. 296-314, 2003.

SOUZA, F. X.; COSTA, J. T. A. Produção de mudas das Spondias cajazeira, cirigueleira, umbu -cajazeira e umbuzeiro. 1. ed. Fortaleza, CE: EMBRAPA, 2010. 26 p. (Embrapa Agroindústria Tropical. Documentos, 133).

STEEL, R. G. D.; TORRIE, J. H. Principles and procedures of statistics: a biometrical approach. 2 . ed. New York: McGraw-Hill, 1980. 633 p.

THOMAS, P.; SCHIEFELBEIN, J. Cloning and characterization of an actin depolymerizing factor gene from grape (Vitis vinifera L.) expressed during rooting in stem cuttings. Plant Science, v. 162, n. 2, p. 283-288, 2002.

TOSTA, M. S. et al. Ácido indolbutírico na propagação vegetativa de cajaraneira (Spondias sp.). Semina: Ciências Agrárias, v. 33, n. 6, p. $2727-$ $2740,2012$.

VIEIRA, A. R. Propagação assexuada e qualidade de frutos de genótipos de umbu-cajazeira da mesorregião Centro-Sul do Ceará. 2013. 155 f. Tese (Doutorado em Fitotecnia: Área de concentração: Agricultura Tropical) Universidade Federal Rural do Semi-Árido, Mossoró, 2013. 